\title{
Effectiveness of rubber seed oil and flaxseed oil to enhance the a-linolenic acid content in milk from dairy cows
}

\author{
Y. Pi, ${ }^{*}$ S. T. Gao, ${ }^{*}$ L. Ma, ${ }^{*} †$ Y. X. Zhu, $\ddagger$ J. Q. Wang, ${ }^{*}$ J. M. Zhang, ${ }^{*}$ J. C. Xu, ${ }^{*} \ddagger \#$ and D. P. Bu${ }^{*} \dagger \S^{1}$ \\ *Institute of Animal Science, State Key Laboratory of Animal Nutrition, Chinese Academy of Agricultural Sciences, Beijing, 100193, P. R. China \\ †Chinese Academy of Agricultural Sciences (CAAS) and World Agroforestry Center (ICRAF) Joint Laboratory on Agroforestry \\ and Sustainable Animal Husbandry, Beijing 100193, China \\ ¥Key Laboratory of Economic Plants and Biotechnology, Kunming Institute of Botany, Chinese Academy of Sciences, Kunming, 650201, China \\ $\S$ Synergetic Innovation Center of Food Safety and Nutrition, Harbin, 150030, China \\ \#CAAS-ICRAF Joint Laboratory on Agroforestry and Sustainable Animal Husbandry, World Agroforestry Centre, East and Central Asia Region, \\ Kunming 650201, China
}

\section{ABSTRACT}

This experiment was conducted to investigate effect of rubber seed oil compared with flaxseed oil when fed alone or in combination on milk yield, milk composition, and $\alpha$-linolenic acid (ALA) concentration in milk of dairy cows. Forty-eight mid-lactation Holstein dairy cows were randomly assigned to 1 of 4 treatments according to a completely randomized design. Cows were fed a basal diet (control; CON) or a basal diet supplemented with $4 \%$ rubber seed oil (RO), $4 \%$ flaxseed oil (FO), or $2 \%$ rubber seed oil plus $2 \%$ flaxseed oil (RFO) on a dry matter basis for 9 wk. Feed intake, milk protein percentage, and milk fat levels did not differ between the treatments. Cows fed the RO, FO, or RFO treatments had a higher milk yield than the CON group (up to $10.5 \%$ more), whereas milk fat percentages decreased. Compared with the CON, milk concentration of ALA was substantially higher in cows receiving $\mathrm{RO}$ or $\mathrm{RFO}$, and was doubled in cows receiving FO. The ALA yield (g/d) increased by 31.0, 70.3, and $33.4 \%$ in milk from cows fed RO, FO, or RFO, respectively, compared with the CON. Both C18:1 trans-11 (vaccenic acid) and C18:2 cis-9,trans-11 (conjugated linoleic acid; CLA) levels were higher in cows fed added flaxseed or rubber seed oil. The CLA yield (g/d) increased by 336,492 , and $484 \%$ in cows fed RO, FO, or RFO, respectively, compared with the CON. The increase in vaccenic acid, ALA, and CLA was greater in cows fed RFO than in cows fed RO alone. Compared with the CON, the milk fat from cows fed any of the dietary supplements had a higher concentration of unsaturated fatty acids, monounsaturated fatty acids, and polyunsaturated fatty acids; conversely, the saturated fatty acids levels in milk fat were $30.5 \%$

Received January 4, 2015

Accepted March 26, 2016.

${ }^{1}$ Corresponding author: budengpan@126.com lower. Insulin and growth hormones were not affected by dietary treatments; however, we noted an increase in both cholesterol and nonesterified fatty acids levels in the RO, FO, or RFO treatments. These results indicate that rubber seed oil and flaxseed oil will increase milk production and the concentration of functional fatty acids (ALA, vaccenic acid, and CLA) in milk fat while decreasing the content of saturated fatty acids.

Key words: rubber seed oil, flaxseed oil, $\alpha$-linolenic acid, milk fat

\section{INTRODUCTION}

Foods derived from animals are an important source of nutrients to humans. Milk and dairy products are a major source of SFA in most countries diets (Givens, 2008); however, certain SFA have been found to increase the risk of cardiovascular disease and cardiometabolic disease (Givens, 2015). $\alpha$-Linolenic acid (ALA), an n-3 PUFA with 18 carbons and 3 cis double bonds, is one of the major essential fatty acids in the human diet (Burdge, 2006). However, in normal bovine milk fat ALA is found in small amounts $(<1.0 \%$ by weight) because of ruminal biohydrogenation of dietary UFA. Thus, changing the composition of milk fat fatty acids by increasing essential fatty acids (ALA or other PUFA) content and decreasing the less healthy fatty acid (SFA) content might be beneficial to the health of consumers.

Milk fat content and fatty acid profile in milk and dairy products can be extensively modified by nutritional factors, in particular dietary fat supplements (Shingfield et al., 2008). The main source of unsaturated lipids are vegetable oils such as sunflower, soybean, linseed, and corn oil. These oils were added to ruminant diets to enhance the proportion of desirable UFA in edible products ( $\mathrm{Bu}$ et al., 2007; Tsiplakou and Zervas, 2013), or to increase the energy density of the ration. However, increasing the level of ALA in 
ruminant milk seems particularly difficult because of extensive biohydrogenation (BH) in the rumen, resulting in a relatively low transfer rate from the diet into milk (Sampelayo et al., 2007). Additionally, including oil-rich UFA in dairy cow diets can cause a reduction in DMI and milk fat content (Whitlock et al., 2002; Shingfield et al., 2006).

Flaxseed oil and rubber seed oil are rich in ALA (Bashar and Jumat, 2010). Flaxseed oil contains a high level of ALA, constituting approximately $55 \%$ of the oil's total fatty acids (Petit, 2003). In rubber seed oil, the total UFA, PUFA, and ALA content can amount to 83,59 , and $22 \%$, respectively. Thus, feeding dairy cows with flaxseed or rubber seed oil may improve milk yield and the milk fatty acid profile, especially ALA. The objective of our study was to determine the effects of the addition of flaxseed or rubber seed oil alone or in combination on milk yield and milk fatty acid profile, with a particular emphasis on ALA.

\section{MATERIALS AND METHODS}

\section{Cows, Experimental Design, and Treatments}

The present study was performed at Tianjin Mengde Dairy Farm (Tianjin, China). Animals were cared for in accordance with the guidelines established by the Institute of Animal Science, Chinese Academy of Agriculture Sciences, Beijing, China.

Forty-eight mid-lactation Holstein dairy cows (163 $\pm 25.3 \mathrm{DIM}, 29.6 \pm 2.42 \mathrm{~kg}$ of milk/d, and parity 1.8 $\pm 1.25)$ were used in a completely randomized design. The animals were randomly assigned to 4 dietary treatments. The total duration of the experiment was $9 \mathrm{wk}$, during which the cows were fed a basal diet (control; CON) or the basal diet supplemented with $4 \%$ rubber seed oil (RO), $4 \%$ flaxseed oil (FO), or $2 \%$ rubber seed oil plus $2 \%$ flaxseed oil (RFO) on a DM basis. The flaxseed oil was supplied by Huajian Axunge Co., Ltd. (Shanxi, China) and the rubber seed oil by Kunming Institute of Botany, Chinese Academy of Sciences (Kunming, China). The ingredients and chemical composition of the diets are presented in Table 1 . The diet was formulated to meet or exceed the nutrient demand of energy, protein, minerals, and vitamins according to the Feeding Standards of Dairy Cattle, China NongYe HangYe Biaozhun/Tuijian-34 (China, NY/T 34; People's Republic of China, 2004). All cows were housed in a well-ventilated barn and fed individually, with free access to fresh water. At the beginning of the study, cows were gradually adjusted to the experimental diets over a 1-wk period. Diets were fed as a TMR 3 times a day to ensure $10 \%$ refusals (at 0530,1330 , and $1800 \mathrm{~h}$ ). The oils were stored at $4^{\circ} \mathrm{C}$ and were added fresh as the final component of the diet at each feeding to avoid oxidation.

\section{Sampling, Measurements, and Analysis}

Samples of the feed offered and the refusals were recorded every day for each individual cow and frozen at $-20^{\circ} \mathrm{C}$ until analysis. Weekly representative samples of TMR and orts from each treatment were analyzed for DM content by oven-drying at $60^{\circ} \mathrm{C}$ to a constant weight. Dietary formulations were adjusted weekly to account for any changes in ingredient DM content. The dried samples were ground through a 1-mm screen using a Cyclotec 1093 Mill (Tecator 1093, Tecator AB, Höganäs, Sweden) before analysis. Samples were further dried at $105^{\circ} \mathrm{C}$ for $2 \mathrm{~h}$ to determine the absolute $\mathrm{DM}$, and chemical analyses were expressed on the basis of the final absolute DM. The $\mathrm{CP}(\mathrm{N} \times 6.25)$ content of feed samples was determined using the macro-Kjeldahl nitrogen test (AOAC International, 2000; method 976.05) with a Kjeltec digester 20 and a Kjeltec System 1026 distilling unit (Tecator AB). The contents of NDF and $\mathrm{ADF}$ were determined using procedure A by Van Soest et al. (1991) using heat-stable amylase (type XI-A of Bacillus subtilis; Sigma-Aldrich, St. Louis, MO), but without sodium sulfite for the NDF. The ash content was determined by incineration at $550^{\circ} \mathrm{C}$ overnight, and the OM content calculated (AOAC International, 2000; method 942.05). The ether extract content was determined using a Soxtec system HT6 apparatus (Tecator AB) according to AOAC International (2000; method 920.39). The calcium and phosphorous contents were determined according to AOAC International (2000; method 935.13). Weekly samples of TMR were also analyzed for their fatty acid profile according to the procedure of Sukhija and Palmquist (1988).

Cows were milked 3 times daily (at 0500, 1300, and $2100 \mathrm{~h}$ ) with individual milk yields recorded at each milking. On the last day of each week, duplicate milk samples from individual cows were collected at 3 consecutive milkings and mixed based on the average milk production at each milking (morning, afternoon, and night; volume ratio: 4:3:3). One aliquot of milk was preserved with bronopol- $\mathrm{B}_{2}$ preservative (D\&F Control System Inc., Dublin, ON, Canada) at $4^{\circ} \mathrm{C}$ and subsequently analyzed for fat, protein, lactose, SCC, TS, and SNF using a mid-infrared machine (Foss MilkoScan, Foss Food Technology Corp., Eden Prairie, MN). Another aliquot of milk was stored at $-70^{\circ} \mathrm{C}$ for further fatty acid analysis. The ECM and 4\% FCM were calculated using the equations: $\mathrm{ECM}=0.327 \times$ milk $(\mathrm{kg})$ $+12.95 \times$ fat $(\mathrm{kg})+7.20 \times$ protein $(\mathrm{kg})$ and $4 \% \mathrm{FCM}$ $=0.4 \times$ milk $(\mathrm{kg})+15 \times$ fat $(\mathrm{kg})$ (Tyrrell and Reid, 1965). Feed efficiency was calculated as the daily ECM 
Table 1. Ingredient and chemical composition of the experimental diets

\begin{tabular}{|c|c|c|c|c|c|}
\hline \multirow[b]{2}{*}{ Item } & \multicolumn{4}{|c|}{ Treatment $^{1}$} & \multirow[b]{2}{*}{$\mathrm{SD}$} \\
\hline & $\mathrm{CON}$ & $\mathrm{RO}$ & FO & RFO & \\
\hline \multicolumn{6}{|l|}{ Diet ingredient, $\%$ of $\mathrm{DM}$} \\
\hline Alfalfa hay & 19.9 & 19.9 & 19.9 & 19.9 & 1.28 \\
\hline Chinese wildrye & 3.8 & 3.8 & 3.8 & 3.8 & 0.37 \\
\hline Corn silage & 24.6 & 24.6 & 24.6 & 24.6 & 1.92 \\
\hline Corn & 17.8 & 16.2 & 16.2 & 16.2 & 1.44 \\
\hline Flaked corn & 6.3 & 5.7 & 5.7 & 5.7 & 0.62 \\
\hline Soybean meal & 11.5 & 10.5 & 10.5 & 10.5 & 0.98 \\
\hline Soy hulls & 2.5 & 2.3 & 2.3 & 2.3 & 0.30 \\
\hline Dry distillers grains with solubles & 3.8 & 3.5 & 3.5 & 3.5 & 0.40 \\
\hline Double-low rapeseed meal (DLRM) & 3.9 & 3.6 & 3.6 & 3.6 & 0.36 \\
\hline Molasses $(30 \%)$ & 2.5 & 2.5 & 2.5 & 2.5 & 0.24 \\
\hline Rubber seed oil & - & 4.0 & - & 2.0 & 0.06 \\
\hline Flaxseed oil & - & - & 4.0 & 2.0 & 0.06 \\
\hline Sodium bicarbonate & 0.5 & 0.5 & 0.5 & 0.5 & 0.04 \\
\hline Dicalcium phosphate & 0.3 & 0.3 & 0.3 & 0.3 & 0.02 \\
\hline Salt & 0.5 & 0.5 & 0.5 & 0.5 & 0.02 \\
\hline Calcium carbonate & 0.9 & 0.9 & 0.9 & 0.9 & 0.06 \\
\hline Vitamin-mineral premix ${ }^{2}$ & 1.2 & 1.2 & 1.2 & 1.2 & 0.09 \\
\hline \multicolumn{6}{|c|}{ Chemical, $\%$ of DM (unless otherwise noted) } \\
\hline $\mathrm{DM}, \%$ & 49.7 & 50.6 & 50.6 & 50.6 & 0.39 \\
\hline $\mathrm{NE}_{\mathrm{L}},{ }^{3} \mathrm{Mcal} / \mathrm{kg}$ of DM & 1.61 & 1.73 & 1.73 & 1.73 & 0.06 \\
\hline $\mathrm{CP}$ & 16.6 & 16.1 & 16.1 & 16.1 & 0.21 \\
\hline NDF & 35.0 & 34.4 & 34.4 & 34.4 & 0.26 \\
\hline $\mathrm{ADF}$ & 21.8 & 21.5 & 21.5 & 21.5 & 0.12 \\
\hline $\mathrm{Ca}$ & 1.10 & 1.06 & 1.06 & 1.06 & 0.02 \\
\hline $\mathrm{P}$ & 0.36 & 0.35 & 0.35 & 0.35 & 0.01 \\
\hline
\end{tabular}

${ }^{1}$ Cows were fed a basal diet (control; CON) or basal diet supplemented with either $4.0 \%$ rubber seed oil (RO), $4.0 \%$ flaxseed oil (FO), or $2.0 \%$ rubber seed oil $+2.0 \%$ flaxseed oil (RFO). The CON diet was also used for feeding during the pretrial period.

${ }^{2}$ Contained (per $\mathrm{kg}$ of DM): a minimum of 313,500 IU of vitamin A, 104,500 IU of vitamin D, 5,000 IU of vitamin E, $780 \mathrm{mg}$ of $\mathrm{Cu}, 780 \mathrm{mg}$ of $\mathrm{Fe}, 780 \mathrm{mg}$ of $\mathrm{Mn}, 3,900 \mathrm{mg}$ of $\mathrm{Zn}, 30 \mathrm{mg}$ of Se, $50 \mathrm{mg}$ of I, and $65 \mathrm{mg}$ of Co.

${ }^{3}$ Calculated value (based on China Standard NY/T 34; People's Republic of China, 2004).

yield per kilogram of feed DMI on an individual-cow basis.

Milk fatty acid analysis was conducted using the method described by $\mathrm{Bu}$ et al. (2007), with minor modifications as follows. The frozen milk samples were thawed in a refrigerator at $4^{\circ} \mathrm{C}$ and centrifuged at 5,000 $\times g$ for $30 \mathrm{~min}$ at $8^{\circ} \mathrm{C}$ to separate the fat, and $20 \mathrm{mg}$ of the fat cake was transferred to a 5 - $\mathrm{mL}$ tube. The saponification and methyl esterification of the fat were performed using the method containing $\mathrm{NaOCH}_{3} /$ methanol followed by $\mathrm{HCl} /$ methanol, as described by Kramer et al. (1997). Fatty acid methyl esters were separated using an Agilent 6890N gas chromatograph (Agilent Technologies, Santa Clara, CA) fitted with a flame-ionization detector. The samples containing methyl esters in hexane $(2 \mu \mathrm{L})$ were injected through the split injection port (50:1) onto an HP-88 fused silica $100 \mathrm{~m} \times 0.25 \mathrm{~mm}$ column with a $0.20-\mu \mathrm{m}$ film (J\&W Scientific, Folsom, CA). The oven temperature was initially $120^{\circ} \mathrm{C}$ for $10 \mathrm{~min}$, and was then increased at $1.5^{\circ} \mathrm{C} / \mathrm{min}$ to $230^{\circ} \mathrm{C}$ and then held for $30 \mathrm{~min}$. The injector and detector temperatures were maintained at $250^{\circ} \mathrm{C}$ and $280^{\circ} \mathrm{C}$, respectively, and the total run time was $113.33 \mathrm{~min}$.

In this study, a qualitative external standard method was used. Each peak was identified using known standards of FAME. The FAME standards for C18:1 trans-11, C20:2, C20:3 cis-8,cis-11,cis-14, C20:3 cis11,cis-14,cis-17, C22:2, C22:3, C22:4, and C22:5 were purchased from sigma (Sigma-Aldrich). Cis-9,trans-11 CLA and trans-10,cis-12 CLA were purchased from Larodan (Limhamn, Sweden). The NLEA FAME Mix (28 components) was purchased from Restek (Bellefonte, PA). C17:0 was used for quality control to calculate the recovery rate for each batch (every 30 samples) of milk fat separation. The FAME data were converted to a fatty acid base by multiplying a correction factor according to the methods of Kaylegian et al. (2009). Gas chromatography-MS (Agilent 6890N5975C, Agilent Technologies) was applied against the NIST10 (National Institute of Standards and Technology, Gaithersburg, MD) spectrum library for further identification of each peak. The conditions of the GC were the same as that for the FAME, with the MS 
operated in scan mode $(\mathrm{m} / z 50$ to 550 , electron impact ionization voltage $70 \mathrm{eV}$, ion source temperature $230^{\circ} \mathrm{C}$, and interface temperature $280^{\circ} \mathrm{C}$ ). The results showed that the peak for C18:1 trans-11 was not mixed with C18:1 trans-10 (matching rate of $\mathrm{C} 18: 1$ trans-11 was as high as 99\%). Because of the lack of a FAME standard, C18:1 trans-10 was not quantified and reported.

Results for each fatty acid were reported as grams per 100 grams of the sum of all identified fatty acids. The yield of fatty acids was calculated by multiplying the individual milk fatty acids by milk fat yield and by a coefficient of $93.3 \%$ (Glasser et al., 2007). Desaturase ratios between cis-9 UFA and their precursors, which can serve as a proxy for $\Delta^{9}$-desaturase activity (Bauman et al., 2001), were calculated as described by Kelsey et al. (2003).

Blood samples were collected during wk 3, 5, 7 of the experiment at the same time of the day on each of those weeks. Approximately $15 \mathrm{~mL}$ of duplicate blood samples from individual cows were collected from the coccygeal vein $4 \mathrm{~h}$ after feeding (at $0930 \mathrm{~h}$ ). One aliquot of blood sample was collected in serum separator tubes (Serum Clot Activator, Greiner Bio One GmbH, Kremsmunster, Austria), and the samples were allowed to clot for a minimum of $25 \mathrm{~min}$ at $20^{\circ} \mathrm{C}$ and stored in the refrigerator overnight. The samples were then centrifuged at $3,000 \times g$ for $15 \mathrm{~min}$ at $4^{\circ} \mathrm{C}$ before separation of the serum. Another aliquot of blood was collected into heparinized tubes containing anticoagulant (lithium heparin, Greiner Bio One $\mathrm{GmbH}$ ) plasma and centrifuged at $3,000 \times g$ for $15 \mathrm{~min}$ at $4^{\circ} \mathrm{C}$ to separate the plasma. Plasma and serum were stored at $-70^{\circ} \mathrm{C}$ until analysis. Plasma was analyzed for phospholipids using a phospholipid kit (Sino-German Beijing Leadman Bio Tech Ltd., Beijing, China); low-density lipoprotein cholesterol (LDLP) and high-density lipoprotein cholesterol (HDLP) were analyzed by an immunoseparation method using an Olympus AU2700 auto analyzer (Olympus, Tokyo, Japan) and kits obtained from Shanghai Fortune Long March Medical Science Co. Ltd. (Shanghai, China; Lichtenstein et al., 1993). It should be noted that although the methods are commonly used in human clinical measurement, they have not been validated for use in bovines. Plasma was also analyzed for glucose (Trinder, 1969), cholesterol (Fossati and Prencipe, 1982), and triglycerides (McNamara and Schaefer, 1987; using kits from Zhongsheng Beikong Bio-Technology and Science Inc., Beijing, China); for growth hormone (Reynaert and Franchimont, 1974; GH kit, Beijing North Institute of Biological Technology, Beijing, China); and for insulin (Starr et al., 1979; INS kit, Beijing North Institute of Biological Technology). The serum was analyzed for BHB (McMurray et al., 1984) and NEFA (Matsubara et al., 1983) through an enzymatic method using kits (Randox Laboratories Ltd., Antrim, UK). The intra-assay coefficients of variation for growth hormone, insulin, cholesterol, LDLP, and HDLP were $9,15,1.2,3$, and $3 \%$, respectively. The interassay coefficients of variation for growth hormone, insulin, cholesterol, LDLP, and HDLP were 13, 10, 2.7, 5 , and $5 \%$, respectively.

\section{Statistical Analysis}

The data for DMI, milk yield, milk composition, milk fatty acid composition, and blood parameters were analyzed as a completely randomized design with repeated measures using PROC MIXED of SAS (version 9.2, SAS Institute Inc., Cary, NC). The fixed effects in the model included treatment, week (week for DMI, milk yield, milk composition, milk fatty acid composition, and blood parameters), and treatment $\times$ week interaction. The variance for cow nested within treatment was used as random error term to test the main effect of the treatment. The data of pre-experiment were used as covariates and the cow variance was considered random. The subject was cow within treatment and repeated parameter was week. The covariance structure was autoregressive [AR (1)], and denominator degrees of freedom using the Kenward-Roger method. The data are presented as covariates adjusted least squares means with their standard error of the mean. The significance level was declared at $P<0.05$ and trends for significance were declared at $P=0.05$ and a trend at $P$ $<0.10$. The MIXED statistical model used for analysis was as follows:

$$
\begin{aligned}
\mathrm{Y}_{\mathrm{ijk}}= & \mu+\mathrm{T}_{\mathrm{i}}+\mathrm{D}_{\mathrm{j}(\mathrm{i})}+\mathrm{W}_{\mathrm{k}}+(\mathrm{TW})_{\mathrm{ik}} \\
& \times\left(\mathrm{b}+\Phi_{\mathrm{j}}\right)+\mathrm{X}_{\mathrm{ij}}+\mathrm{E}_{\mathrm{ijk}},
\end{aligned}
$$

where $Y_{\mathrm{ijk}}=$ dependent variable measured at week $\mathrm{k}$ on the jth cow assigned to the ith treatment, $\mu=$ population mean, $\mathrm{T}_{\mathrm{i}}=$ treatment effect, $\mathrm{D}_{\mathrm{j}(\mathrm{i})}=$ random effect of the jth cow within the ith treatment, $\mathrm{W}_{\mathrm{k}}=$ week effect, $(\mathrm{TW})_{\mathrm{ik}}=$ fixed interaction effect between treatment and week, $\mathrm{b}=$ the common regression coefficient of pre-experiment data of $\mathrm{X}_{\mathrm{ij}}, \Phi \mathrm{j}=$ the slope deviation of the ith treatment from the common slope $\mathrm{b}, \mathrm{X}_{\mathrm{ij}}=$ the DIM data of cow $j$ on treatment $i$, and $E_{i j k}=$ random error associated with the jth cow assigned to the ith treatment in week $\mathrm{k}$.

\section{RESULTS AND DISCUSSION}

\section{Chemical Composition of Diets}

The chemical composition of the diets is presented in Table 1. The DM content of the experimental diets 
ranged from 49.6 to $50.7 \%$. The energy content of the diets increased in $\mathrm{RO}, \mathrm{FO}$, and $\mathrm{RFO}$ in comparison with the CON (mean value for RO, FO, and RFO of 1.73 vs. $1.61 \mathrm{Mcal} / \mathrm{kg}$ of $\mathrm{DM}$ for the $\mathrm{CON})$. The $\mathrm{CP}$, $\mathrm{NDF}, \mathrm{ADF}, \mathrm{Ca}$, and $\mathrm{P}$ contents of the diets met the levels recommended for dairy cows with production levels used in the experiment (People's Republic of China, 2004).

The total fatty acid content and composition of the experimental diets were changed by $\mathrm{RO}, \mathrm{FO}$, and $\mathrm{RFO}$ (Table 2). The total fatty acid content of the RO, FO, and RFO diets was nearly 3 times higher than the CON diet (mean value for $\mathrm{RO}, \mathrm{FO}$, and $\mathrm{RFO}$ of $6.37 \mathrm{vs}$. $2.39 \%$ of diet DM for the CON). Dietary crude fat in oil treatments approached the maximum recommended level for dairy cows (7 to $8 \%$ of diet DM; NRC, 2001). Both rubber seed oil and flaxseed oil are rich in C18:3, C18:2 cis-9, and C18:1 cis-9 (Bashar and Jumat, 2010). The content of C18:3 in flaxseed oil is higher than the content in rubber seed oil (57.5 vs. $24.9 \%$ ). By contrast, the content of C18:2 cis-9 in rubber seed oil is higher than in flaxseed oil (36.66 vs. 15.19\%). These measured values of fatty acid composition in rubber seed oil and flaxseed oil were similar to the values of previous studies (Petit, 2003). In the current study, the content of C18:3 in diets was $9.06,18.33,38.59$, and $29.18 \%$ in the CON, RO, FO, and RFO treatments, respectively. Therefore, increased proportions of C18:1 cis-9, C18:2 cis-9, and $\mathrm{C} 18: 3$ in RO, FO, and RFO compared with the CON diet reflect the addition of these fatty acids from rubber seed and flaxseed oils to the diet.

Table 2. Fatty acid (FA) content and composition of experimental diets supplemented with rubber seed oil and flaxseed oil or in combination

\begin{tabular}{lrrrr}
\hline & \multicolumn{4}{c}{ Treatment $^{1}$} \\
\cline { 2 - 5 } Item & CON & \multicolumn{1}{c}{ RO } & FO & RFO \\
\hline Total FA, \% diet DM & 2.79 & 6.37 & 6.32 & 6.26 \\
FA, ${ }^{2} \%$ of total FA reported & & & & \\
C14:0 & 0.39 & 0.23 & 0.20 & 0.20 \\
C16:0 & 18.16 & 12.33 & 10.05 & 11.08 \\
C16:1 & 0.55 & 0.36 & 0.24 & 0.31 \\
C17:0 & 0.17 & 0.10 & 0.10 & 0.10 \\
C18:0 & 2.58 & 5.23 & 2.91 & 3.98 \\
C18:1 cis-9 & 21.97 & 21.70 & 19.38 & 20.50 \\
C18:2 cis-9, cis-12 & 44.66 & 40.18 & 27.12 & 33.38 \\
C18:3 & 9.06 & 18.33 & 38.59 & 29.18 \\
C20:0 & 0.51 & 0.39 & 0.27 & 0.32 \\
C20:1 & 0.23 & 0.21 & 0.20 & 0.20 \\
C22:0 & 0.44 & 0.25 & 0.26 & 0.26 \\
C22:2 & 0.46 & 0.22 & 0.22 & 0.21 \\
\hline
\end{tabular}

${ }^{1}$ Cows were fed a basal diet (control; CON) or basal diet supplemented with either $4.0 \%$ rubber seed oil (RO), $4.0 \%$ flaxseed oil (FO), or $2.0 \%$ rubber seed oil $+2.0 \%$ flaxseed oil (RFO). The CON diet was also used for feeding during the pretrial period.

${ }^{2}$ Expressed as number of carbons:number of double bonds.

\section{Feed Intake and Milk Yield}

Supplementing rubber seed oil or flaxseed oil at $4 \%$ of the dietary DM separately or in combination had no effect $(P>0.05)$ on the daily DMI (Table 3$)$. The effect of supplementary oil on the daily DMI of dairy cows is variable, with several factors influencing intake, including palatability, fatty acid chain length, fatty acid saturation, and the form of fat (e.g., free fatty acid, triglycerides, glycolipids; Allen, 2000). In the current study, the DMI results are similar to previous studies in lactating dairy cows when fed with flaxseed oil at 4 to $6 \%$ of the diet DM (Bu et al., 2007). Similarly, Benchaar et al. (2012) reported that supplementation with flaxseed oil at 2, 3, or $4 \%$ of the diet DM had no effect on DMI. By contrast, Martin et al. (2008) observed that supplementing flaxseed oil at $5.7 \%$ of the diet DM decreased DMI by $25.8 \%$ in dairy cows. The different effects of these oil supplements on the DMI may be attributed to the oil palatability, the amounts added, and the varying ratio of concentrate to roughage in these studies.

Supplementing fat through feeding RO or FO separately, or in combination (RFO) at $4 \%$ of the diet DM resulted in an average increase $(P<0.001)$ in milk yield of $10.98 \%$ (14.02, 10.98, and $7.95 \%$ for RO, FO, and RFO respectively; Table 3). Previous research on oil supplementation has often shown little to no effect on milk yield (Lock and Garnsworthy, 2002; Tsiplakou and Zervas, 2013). Moreover, Martin et al. (2008) reported that the milk yield of dairy cows supplemented with linseed oil decreased. The current finding that milk yield increased significantly when the diet was supplemented with oil is consistent with $\mathrm{Bu}$ et al. (2007), who reported that the milk yield increased in dairy cattle supplemented with soybean oil or flaxseed oil at $4 \%$ of the diet DM. Oil is high in energy and, theoretically, supplemental fat increases energy intake; thus, the severity of negative energy balance may be reduced, resulting in improved performance and improved reproductive efficiency (Grummer and Carroll, 1991). In the current study, supplementing with oil increased the energy content of diets but had no influence on the DMI compared with the cows in the CON group (without supplemental oil); therefore, energy intake was increased. Moreover, the gross feed efficiency (calculated as ECM produced $/ \mathrm{kg}$ of the DMI) of RO, $\mathrm{FO}$, and RFO treatments was higher $(P>0.05)$ than in the CON group (averaging 1.37, 1.33, and 1.41 vs. 1.36, respectively). Interestingly, each oil treatment had a similar effect on milk yield, suggesting that oils rich in different proportions of UFA affected the performance of the animals in a similar way. 
Table 3. Dry matter intake, milk yield, and milk compositions of cows fed diets supplemented with rubber seed oil and flaxseed oil or in combination

\begin{tabular}{lcccccr}
\hline & \multicolumn{7}{c}{ Treatment $^{1}$} & & \\
\cline { 2 - 5 } Item & CON & RO & FO & RFO & \multirow{2}{*}{ SEM $^{2}$} & $P$-value \\
\hline DMI, kg/d & 20.2 & 20.5 & 19.8 & 19.9 & 0.26 & 0.43 \\
Milk yield, kg/d & $26.4^{\mathrm{b}}$ & $30.1^{\mathrm{a}}$ & $29.3^{\mathrm{a}}$ & $28.5^{\mathrm{a}}$ & 0.43 & $<0.01$ \\
$4 \%$ FCM, ${ }^{3} \mathrm{~kg} / \mathrm{d}$ & 25.3 & 25.1 & 25.4 & 24.6 & 0.35 & 0.20 \\
ECM, ${ }^{4} \mathrm{~kg} / \mathrm{d}$ & $27.6^{\mathrm{b}}$ & $27.3^{\mathrm{a}}$ & $28.0^{\mathrm{ab}}$ & $27.1^{\mathrm{b}}$ & 0.14 & $<0.01$ \\
Efficiency, ECM/DMI & 1.37 & 1.33 & 1.41 & 1.36 & 0.068 & 0.54 \\
Milk fat, \% & $3.62^{\mathrm{a}}$ & $3.13^{\mathrm{b}}$ & $3.27^{\mathrm{b}}$ & $3.16^{\mathrm{b}}$ & 0.099 & $<0.01$ \\
Milk fat yield, kg/d & 0.98 & 0.91 & 0.93 & 0.88 & 0.028 & 0.08 \\
Milk protein, \% & 3.31 & 3.22 & 3.21 & 3.29 & 0.079 & 0.70 \\
Milk protein yield, kg/d & 0.89 & 0.93 & 0.91 & 0.93 & 0.022 & 0.44 \\
Milk lactose, \% & 4.82 & 4.82 & 4.89 & 4.88 & 0.041 & 0.33 \\
Milk lactose yield, kg/d & $1.29^{\mathrm{b}}$ & $1.40^{\mathrm{a}}$ & $1.39^{\mathrm{a}}$ & $1.37^{\mathrm{a}}$ & 0.012 & $<0.01$ \\
SCC, $\times 10^{4} / \mathrm{mL}$ & 29.5 & 45.8 & 54.4 & 42.8 & 7.26 & 0.10 \\
TS, \% & $12.69^{\mathrm{a}}$ & $11.80^{\mathrm{b}}$ & $12.19^{\mathrm{b}}$ & $11.98^{\mathrm{b}}$ & 0.157 & $<0.01$ \\
SNF, \% & 8.89 & 8.71 & 8.91 & 9.00 & 0.082 & 0.10 \\
\hline
\end{tabular}

${ }_{\mathrm{a}, \mathrm{b}}$ Means in the same row with different superscripts differ significantly for treatment effect.

${ }^{1}$ Cows were fed a basal diet (control; CON) or basal diet supplemented with either $4.0 \%$ rubber seed oil (RO), $4.0 \%$ flaxseed oil (FO), or $2.0 \%$ rubber seed oil $+2.0 \%$ flaxseed oil (RFO). The CON diet was also used for feeding during the pretrial period.

${ }^{2}$ Standard error of least squares means.

${ }^{3} 4 \% \mathrm{FCM}=0.4 \times$ milk $(\mathrm{kg})+15 \times$ fat $(\mathrm{kg}) ;$ Tyrrell and Reid, 1965 .

${ }^{4} \mathrm{ECM}=0.327 \times$ milk $(\mathrm{kg})+12.95 \times$ fat $(\mathrm{kg})+7.20 \times$ protein $(\mathrm{kg}) ;$ Tyrrell and Reid, 1965.

\section{Milk Composition}

Milk fat content decreased $(P<0.05)$ in dairy cattle fed the RO, FO, or RFO treatments $(3.19 \%$ on average) compared with the CON $(3.62 \%)$. All treatments except the CON showed a significant drop in milk fat percentage over the whole treatment period (Figure 1). Additionally, milk fat content was similar among the RO, FO, and RFO treatments $(3.13,3.27$, and $3.16 \%$ respectively). As a consequence, the milk fat yield from cows fed RO, FO, or RFO did not differ $(P>0.05)$ compared with the CON group (on average 0.91, 0.93, and 0.88 vs. $0.98 \mathrm{~kg} / \mathrm{d}$, respectively). Previous research on the effects of dietary plant oil supplements on milk fat content has not been consistent. For example, Bu et al. (2007) reported that dietary oil supplements had no effect on the milk fat content in dairy cows. By contrast, Shingfield et al. (2006) reported a marked reduction in the milk fat content with dietary oil supplements, a finding in agreement with the present study. Milk fat depression (MFD) commonly occurs when diets rich in free oil are fed. In the current study, the UFA of rubber seed oil and flaxseed oil were 84.2 and $82.3 \%$, respectively. Increased dietary supply of C18:2 and $\mathrm{C} 18: 3$ fatty acids can also increase trans-C18:1 and other trans-fatty acid production in the rumen due to ruminal $\mathrm{BH}$. It is well established that post-ruminal infusions or supplementation of trans-10,cis-12 CLA inhibit the de novo synthesis of fatty acids in milk from dairy cows and sheep through a reduction in mammary
acetyl-CoA carboxylase and fatty acid synthase activity, and in acetyl-CoA carboxylase mRNA abundance in dairy cows (Baumgard et al., 2002; Sinclair et al., 2010, Hussein et al., 2013). Trans-10 C18:1 has also been reported to be associated with MFD (Shingfield et al., 2006; Flowers et al., 2008); however, trans-10,cis-12 CLA was not detected in milk fat in the current study, and trans-10 C18:1 was not quantified because of the lack of a FAME standard.

Cows in early lactation appear more prone to a fatinduced milk protein depression than those in mid to late lactation phases due to increased vulnerability to a negative nitrogen balance in early lactation (DePeters and Cant, 1992). The cows in the present study were in mid lactation and may not have experienced negative nitrogen balance. Thus, the milk protein content and milk protein yield were not affected by the MFD in the current study, with milk protein content being similar $(P>0.05)$ among the treatments. Furthermore, milk protein yield was higher $(P>0.05)$ in milk from cows fed the RO, FO, or RFO treatments (averaging $0.92 \mathrm{~kg} / \mathrm{d})$ compared with the CON group $(0.89 \mathrm{~kg} / \mathrm{d})$.

\section{Milk Fat Fatty Acid Composition}

Milk fat fatty acid composition (g/100 g of total fatty acids) of cows fed rubber seed oil or flaxseed oil is shown in Table 4. The proportions of short-chain (C4:0, C6:0, C8:0, C10:0, C12:0, and C13:0) and medium-chain fatty acids (C14:0, C14:1, C15:0, C16:0, and 
C16:1) were lower $(P<0.05)$ in milk from cows fed RO, FO, or RFO (Table 4). This result is in agreement with Zheng et al. (2005), who reported that the concentration of C14:0 and C16:0 in milk fat was significantly lower in response to added vegetable oils. Moallem et al. (2012) and Yang et al. (2012) also showed a strong negative correlation between ALA, short-chain, and medium-chain fatty acids in cow milk fat when flaxseed oil and ALA were infused into the digestive tract. Similarly, Bu et al. (2007) reported that the proportion of short-chain and medium-chain fatty acids (C10:0, C12:0, C14:0, and C16:0) was lower in milk from cows that were given soybean oil or flaxseed oil at $4 \%$ of the diet DM compared with CON group. Furthermore, Dai et al. (2011) reported that adding vegetable oils to dairy cow diets can increase the proportion of longchain $(\geq \mathrm{C} 18: 0)$ fatty acids and UFA in milk fat, and decrease the proportions of both short-chain (C4:0 to C12:0) and medium-chain (C14:0 to C16:1) fatty acids.

The proportion of long-chain fatty acids [C18:0, C18:1 trans-9, vaccenic acid (VA), C18:1 cis-9, CLA, and ALA] in milk fat increased $(P<0.05)$ in cows fed $\mathrm{RO}, \mathrm{FO}$ or RFO. As expected, the concentrations of ALA and CLA in milk were enhanced $(P<0.05)$ by RO and FO, which are rich in ALA (22 and 54\%, respectively) and linoleic acid (41 and $13 \%$, respectively). The temporal pattern of milk CLA and ALA enrichment is shown in Figure 2 and demonstrates a remarkable

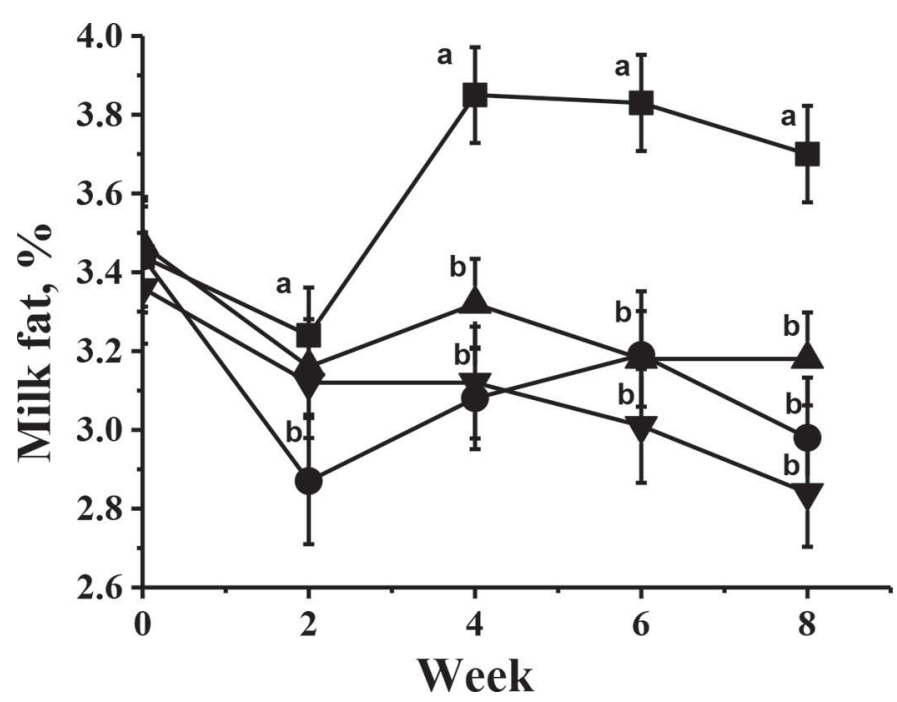

Figure 1. Average milk fat of treatment groups at wk 0, 2, 4, 6, and 8. Control (CON; $\square)=$ diet without added oils; rubber seed oil $(\mathrm{RO} ; \boldsymbol{\bullet})=\mathrm{CON}$ diet including rubber seed oil at $4 \%$ of DM; flaxseed oil $(\mathrm{FO} ; \boldsymbol{\Delta})=\mathrm{CON}$ diet including flaxseed oil at $4 \%$ of DM; rubber seed and flaxseed oil $(\mathrm{RFO} ; \mathbf{\nabla})=\mathrm{CON}$ diet including rubber seed oil at $2 \%$ of DM plus flaxseed oil at $2 \%$ of DM. Data were presented as the mean \pm SEM $(n=12)$. Means at the same week point with different letters $(a, b)$ differ significantly for treatment effect. stability over the whole treatment period. The mean proportion of ALA in milk increased in cows fed FO, $\mathrm{RFO}$, or RO $(0.65,0.53$, and $0.49 \%$, respectively), in line with the increased concentration of ALA in these diets. Moreover, ALA yield $(\mathrm{g} / \mathrm{d})$ increased $(P<0.05)$ by $31.0,70.3$, and $33.4 \%$ in milk from cows fed RO, FO, or RFO, respectively, compared with the CON. Due to the high rates of rumen $\mathrm{BH}$ of ALA, reducing its supply to the small intestine and consequently limiting the supply available to the mammary gland for incorporation into milk fat, the final contents of ALA in milk were modest and seldom surpassed $2 \%$ of the total fatty acids (Martínez Marín et al., 2011). This result was similar to findings by Bu et al. (2007), who showed that the content of ALA in milk reached a maximum of $1 \%$ of the total fatty acids from cows fed flaxseed oil when included at $4 \%$ of the diet DM. Similar increases $(P<$ 0.05) were detected in milk cis-9,trans-11 CLA content, with the absolute amount of CLA being 2.34, 3.19, and $3.25 \%$ in $\mathrm{RO}, \mathrm{FO}$ and $\mathrm{RFO}$ treatments, respectively. The CLA yield (g/d) increased by 336, 492, and $484 \%$ in cows fed RO, FO, or RFO, respectively, compared with the CON. As expected, supplementing unsaturated oils increased CLA and ALA in milk from cows (Loor et al., 2005; Bu et al., 2007), ewes (Gómez-Cortés et al., 2009), and goats (Martínez Marín et al., 2011; Tsiplakou and Zervas, 2013). However, a larger increase was noted in C18:0, C18:1 cis-9, VA, and C18:1 trans-9 in cows fed $\mathrm{RO}$ compared with $\mathrm{FO}$, and lower proportions of CLA were found in RO compared with FO, suggesting that ruminal $\mathrm{BH}$ of UFA was comparatively more complete in dairy cows fed RO than FO.

The CLA found in milk fat originates from 2 sources: VA, which is absorbed and used for endogenous synthesis of CLA, and from CLA that is absorbed and used directly (Griinari et al., 2000). The VA can be converted to CLA in human (Turpeinen et al., 2002) and animal (Corl et al., 2001) body tissues through the enzyme $\Delta^{9}$-desaturase. In the present study, the content of VA in milk was higher $(P<0.05)$ in cows supplemented with rubber seed oil than flaxseed oil. However, the proportion of CLA in milk fat from cows receiving $\mathrm{RO}$ was lower $(P<0.05)$ than with FO. A possible reason may be the higher efficiency for the VA endogenous synthesis of CLA in the FO treatment than the RO, because the $\Delta^{9}$-desaturase enzyme of CLA was higher in FO (0.23 vs. 0.14) in current study. The linolenic acid-rich FO treatment increased milk CLA to a greater extent than the linoleic acid-rich RO treatment. This is inconsistent with the observations of Lock and Garnsworthy (2002) and Bu et al. (2007), who stated that oils rich in linoleic acid (such as soybean oil) are more effective in enhancing CLA in milk fat than those rich in linolenic acid (such as flaxseed oil). Differences 
between studies may be due to the different supplementary amount of oils in the diet influence the rumen BH.

\section{$\Delta^{9}$-Desaturase Enzyme}

It is important to estimate the index of the $\Delta^{9}$ desaturase enzyme that is responsible for the conversion of VA to CLA (Corl et al., 2001). The $\Delta^{9}$-desaturase index for C14:1, C16:1, and C18:1 cis-9 were all higher $(P<0.05)$ in cows fed RO, FO, or RFO than the CON. However, we noted no differences in the $\Delta^{9}$-desaturase index for CLA among the FO, RFO, or CON groups. The $\Delta^{9}$-desaturase index for CLA in cows receiving RO was lower $(P<0.05)$ than in cows fed the FO, RFO, or CON diets (Table 5; Figure 3). The result of $\Delta^{9}$-desaturase enzyme for C18:1 cis-9 in the current study was similar to Allred et al. (2006), who reported that cows fed fish oil had an increased $\Delta^{9}$-desaturase enzyme for C18:1 cis-9 compared with the CON group (who were not fed supplemental oils). Others have reported that the $\Delta^{9}$-desaturase enzyme for $\mathrm{C} 14: 1$ or C16:1 remained unchanged by dietary oil supplementa-

Table 4. Milk fatty acid (FA) composition of cows fed diets supplemented with rubber seed oil and flaxseed oil or in combination

\begin{tabular}{|c|c|c|c|c|c|c|}
\hline \multirow[b]{2}{*}{ Item } & \multicolumn{4}{|c|}{ Treatment $^{2}$} & \multirow[b]{2}{*}{$\mathrm{SEM}^{3}$} & \multirow[b]{2}{*}{$P$-value } \\
\hline & $\mathrm{CON}$ & $\mathrm{RO}$ & $\mathrm{FO}$ & $\mathrm{RFO}$ & & \\
\hline \multicolumn{7}{|l|}{$\mathrm{FA},{ }^{1} \mathrm{~g} / 100 \mathrm{~g}$ of total FA reported } \\
\hline $\mathrm{C} 4: 0$ & $5.47^{\mathrm{a}}$ & $2.43^{\mathrm{c}}$ & $3.69^{\mathrm{b}}$ & $3.24^{\mathrm{bc}}$ & 0.141 & $<0.01$ \\
\hline C6:0 & $3.46^{\mathrm{a}}$ & $1.13^{\mathrm{c}}$ & $1.80^{\mathrm{b}}$ & $1.42^{\mathrm{c}}$ & 0.048 & $<0.01$ \\
\hline $\mathrm{C} 8: 0$ & $1.81^{\mathrm{a}}$ & $0.87^{\mathrm{d}}$ & $1.13^{\mathrm{b}}$ & $0.99^{\mathrm{c}}$ & 0.029 & $<0.01$ \\
\hline C10:0 & $3.52^{\mathrm{a}}$ & $1.27^{\mathrm{d}}$ & $1.82^{\mathrm{b}}$ & $1.47^{\mathrm{c}}$ & 0.071 & $<0.01$ \\
\hline C12:0 & $3.85^{\mathrm{a}}$ & $1.54^{\mathrm{d}}$ & $2.09^{\mathrm{b}}$ & $1.78^{\mathrm{c}}$ & 0.067 & $<0.01$ \\
\hline C13:0 & $0.11^{\mathrm{a}}$ & $0.05^{\mathrm{b}}$ & $0.06^{\mathrm{b}}$ & $0.05^{\mathrm{b}}$ & 0.004 & $<0.01$ \\
\hline C14:0 & $11.22^{\mathrm{a}}$ & $6.58^{\mathrm{d}}$ & $7.91^{\mathrm{b}}$ & $7.34^{\mathrm{c}}$ & 0.191 & $<0.01$ \\
\hline C14:1 & $1.73^{\mathrm{a}}$ & $1.28^{\mathrm{b}}$ & $1.42^{\mathrm{c}}$ & $1.41^{\mathrm{c}}$ & 0.051 & $<0.01$ \\
\hline C15:0 & $0.99^{\mathrm{a}}$ & $0.69^{\mathrm{c}}$ & $0.74^{\mathrm{b}}$ & $0.70^{\mathrm{c}}$ & 0.018 & $<0.01$ \\
\hline C16:0 & $30.32^{\mathrm{a}}$ & $21.10^{\mathrm{b}}$ & $19.68^{\mathrm{c}}$ & $20.54^{\mathrm{bc}}$ & 0.405 & $<0.01$ \\
\hline C16:1 & $1.21^{\mathrm{b}}$ & $1.31^{\mathrm{a}}$ & $1.07^{\mathrm{b}}$ & $1.24^{\mathrm{a}}$ & 0.069 & 0.03 \\
\hline C17:0 & $0.40^{\mathrm{a}}$ & $0.27^{\mathrm{b}}$ & $0.28^{\mathrm{b}}$ & $0.25^{\mathrm{b}}$ & 0.018 & $<0.01$ \\
\hline C18:0 & $9.06^{\mathrm{c}}$ & $12.31^{\mathrm{a}}$ & $10.60^{\mathrm{b}}$ & $10.47^{\mathrm{b}}$ & 0.328 & $<0.01$ \\
\hline C18:1 trans-9 & $0.46^{\mathrm{b}}$ & $1.33^{\mathrm{a}}$ & $1.45^{\mathrm{a}}$ & $1.26^{\mathrm{a}}$ & 0.164 & $<0.01$ \\
\hline C18:1 trans-11 (VA) & $1.91^{\mathrm{c}}$ & $12.97^{\mathrm{a}}$ & $11.67^{\mathrm{b}}$ & $12.27^{\mathrm{ab}}$ & 0.376 & $<0.01$ \\
\hline $\mathrm{C} 18: 1$ cis-9 & $20.77^{\mathrm{b}}$ & $28.99^{\mathrm{a}}$ & $28.11^{\mathrm{a}}$ & $29.16^{\mathrm{a}}$ & 0.584 & $<0.01$ \\
\hline $\mathrm{C} 18: 2$ cis- 9, cis-12 & $2.39^{\mathrm{b}}$ & $2.76^{\mathrm{a}}$ & $2.35^{\mathrm{b}}$ & $2.34^{\mathrm{b}}$ & 0.055 & $<0.01$ \\
\hline $\mathrm{C} 18: 3$ (ALA) & $0.35^{\mathrm{c}}$ & $0.49^{\mathrm{b}}$ & $0.65^{\mathrm{a}}$ & $0.53^{\mathrm{b}}$ & 0.017 & $<0.01$ \\
\hline C18:3 (ALA) yield, (g/d) & $3.26^{\mathrm{c}}$ & $4.27^{\mathrm{b}}$ & $5.55^{\mathrm{a}}$ & $4.35^{\mathrm{b}}$ & 0.142 & $<0.01$ \\
\hline C20:1 & $0.08^{\mathrm{a}}$ & $0.07^{\mathrm{b}}$ & $0.05^{\mathrm{c}}$ & $0.06^{\mathrm{c}}$ & 0.003 & $<0.01$ \\
\hline C18:2 cis-9,trans-11 CLA & $0.52^{\mathrm{c}}$ & $2.34^{\mathrm{b}}$ & $3.19^{\mathrm{a}}$ & $3.25^{\mathrm{a}}$ & 0.169 & $<0.01$ \\
\hline C18:2 cis-9,trans-11 CLA yield, (g/d) & $4.79^{\mathrm{c}}$ & $20.90^{\mathrm{b}}$ & $28.35^{\mathrm{a}}$ & $27.95^{\mathrm{a}}$ & 1.461 & $<0.01$ \\
\hline $\mathrm{C} 20: 0$ & $0.10^{\mathrm{a}}$ & $0.09^{\mathrm{b}}$ & $0.07^{\mathrm{c}}$ & $0.08^{\mathrm{c}}$ & 0.006 & $<0.01$ \\
\hline $\mathrm{C} 22: 0$ & 0.06 & 0.06 & 0.06 & 0.06 & 0.002 & 0.20 \\
\hline $\mathrm{C} 20: 3$ cis-8,cis-11,cis-14 & $0.19^{\mathrm{a}}$ & $0.07^{\mathrm{b}}$ & $0.10^{\mathrm{b}}$ & $0.09^{\mathrm{b}}$ & 0.006 & $<0.01$ \\
\hline \multicolumn{7}{|l|}{ Summations } \\
\hline De novo ${ }^{4}$ & $32.17^{\mathrm{a}}$ & $15.83^{\mathrm{d}}$ & $20.67^{\mathrm{b}}$ & $18.40^{\mathrm{c}}$ & 0.429 & $<0.01$ \\
\hline Mixed $^{5}$ & $31.54^{\mathrm{a}}$ & $22.41^{\mathrm{b}}$ & $20.75^{\mathrm{c}}$ & $21.78^{\mathrm{bc}}$ & 0.407 & $<0.01$ \\
\hline Preformed $^{6}$ & $36.30^{\mathrm{c}}$ & $61.76^{\mathrm{a}}$ & $58.59^{\mathrm{b}}$ & $59.82^{\mathrm{ab}}$ & 0.643 & $<0.01$ \\
\hline $\mathrm{SFA}^{7}$ & $70.39^{\mathrm{a}}$ & $48.39^{\mathrm{c}}$ & $49.94^{\mathrm{b}}$ & $48.39^{\mathrm{bc}}$ & 0.616 & $<0.01$ \\
\hline $\mathrm{UFA}^{8}$ & $29.61^{\mathrm{c}}$ & $51.62^{\mathrm{a}}$ & $50.07^{\mathrm{b}}$ & $51.61^{\mathrm{a}}$ & 0.609 & $<0.01$ \\
\hline MUFA $^{9}$ & $26.17^{\mathrm{d}}$ & $45.95^{\mathrm{a}}$ & $43.78^{\mathrm{c}}$ & $45.40^{\mathrm{b}}$ & 0.512 & $<0.01$ \\
\hline $\mathrm{PUFA}^{10}$ & $3.45^{\mathrm{c}}$ & $5.67^{\mathrm{b}}$ & $6.28^{\mathrm{a}}$ & $6.21^{\mathrm{a}}$ & 0.183 & $<0.01$ \\
\hline
\end{tabular}

\footnotetext{
${ }^{\mathrm{a}-\mathrm{d}}$ Means in the same row with different superscripts differ significantly for treatment effect.

${ }^{1}$ Expressed as number of carbons:number of double bonds. rubber seed oil $+2.0 \%$ flaxseed oil (RFO). The CON diet was also used for feeding during the pretrial period.

${ }^{3}$ Standard error of least squares means.

${ }^{4}$ De novo FA originate from mammary de novo synthesis ( $<16$ carbons).

${ }^{5}$ Mixed FA originate from both sources (C16:0 + C16:1 cis-9).

${ }^{6}$ Preformed FA originate from extraction from plasma ( $>16$ carbons).

${ }^{7}$ Sum of C4:0, C6:0, C8:0, C10:0, C12:0, C13:0, C14:0, C15:0, C16:0, C17:0, C18:0, C20:0 and C22:0.

${ }^{8}$ Total unsaturated FA reported.

${ }^{9}$ Sum of C14:1, C16:1, C18:1 t-11 (VA), C18:1 t-9, C18:1 c-9 and C20:1.

${ }^{10}$ Sum of C18:2 cis-9,cis-12, C18:2 cis-9,trans-11 CLA, C18:3 ALA and C20:3.
}

${ }^{2}$ Cows were fed a basal diet (control; CON) or basal diet supplemented with either $4.0 \%$ rubber seed oil (RO), $4.0 \%$ flaxseed oil (FO), or $2.0 \%$ 

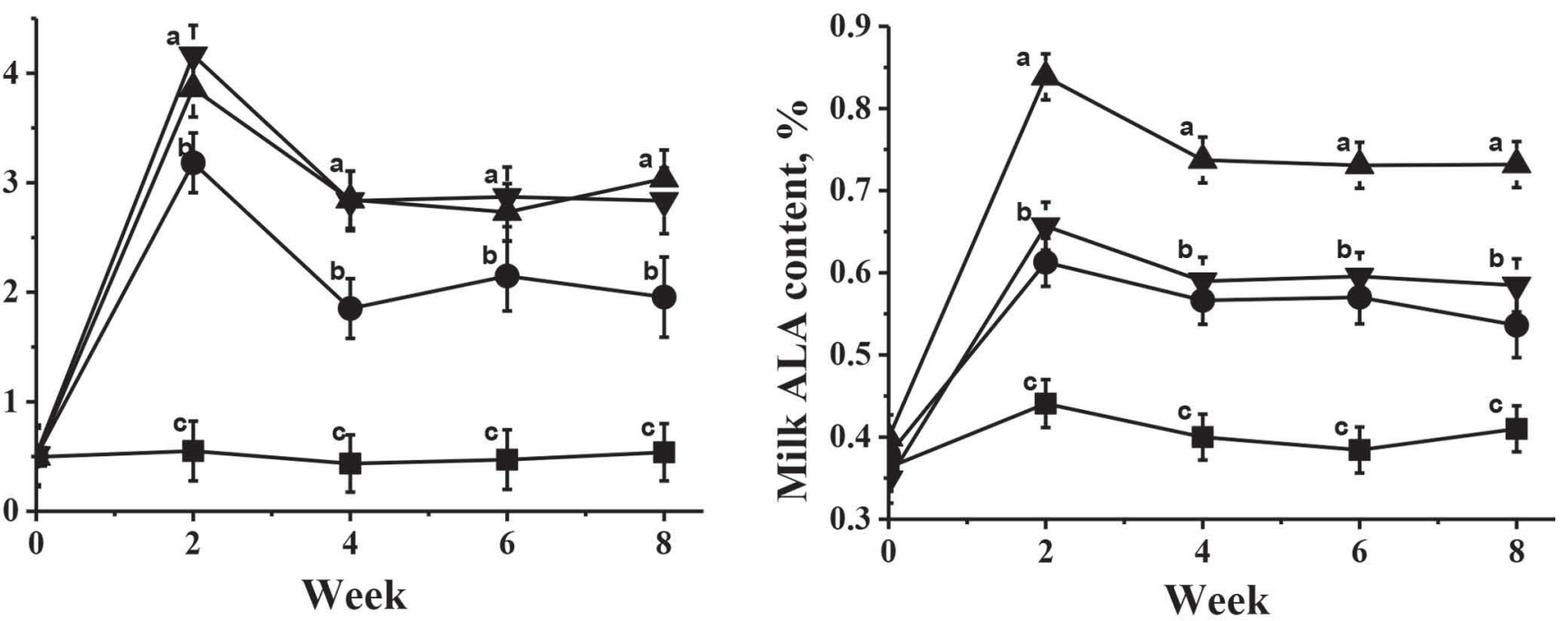

Figure 2. Average milk $\alpha$-linoleic acid (ALA) and cis-9,trans-11 CLA content in milk of treatment groups at wk 0, 2, 4, 6, and 8. Control $(\mathrm{CON} ; \square)=$ diet without added oils; rubber seed oil $(\mathrm{RO} ; \boldsymbol{\bullet})=\mathrm{CON}$ diet including rubber seed oil at $4 \%$ of $\mathrm{DM}$; flaxseed oil $(\mathrm{FO} ; \mathbf{\Delta})=\mathrm{CON}$ diet including flaxseed oil at $4 \%$ of DM; rubber seed and flaxseed oil (RFO; $\mathbf{\nabla})=$ CON diet including rubber seed oil at $2 \%$ of DM plus flaxseed oil at $2 \%$ of DM. Data were presented as the mean \pm SEM $(n=12)$. Means at the same week point with different letters $(\mathrm{a}-\mathrm{c})$ differ significantly for treatment effect.

tion, ranging from 0.04 to 0.08 and from 0.02 to 0.05 , respectively (Lock and Garnsworthy, 2002; Allred et al., 2006; Bu et al., 2007). The increase in C16:1 and C18:1 cis-9 content of milk and the decrease $(P<0.05)$ in $\mathrm{C} 16: 0$ and $\mathrm{C} 14: 0$ content in milk from cows in the $\mathrm{RO}$, FO, or RFO groups may be partially attributed to an increase in $\Delta^{9}$-desaturase enzymatic activity in the mammary gland of the cows in these treatments. The lower desaturase index for CLA in the RO group may explain why it had a higher milk VA concentration with a lower CLA concentration than the FO and RFO treatments. The reason for the lower CLA desaturase ratio in cows receiving $\mathrm{RO}$ is more difficult to explain, as the milk concentration of VA were highest. The CLA content in milk and the $\Delta^{9}$-desaturase index for CLA in cows receiving $\mathrm{RFO}$ or FO were similar, which may suggest that mixing rubber seed oil and flaxseed oil enhances the CLA content of milk by avoiding a decrease in enzyme activity.

\section{Blood Parameters}

Milk fatty acid is synthesized either from fatty acids taken up from the blood or by de novo synthesis in the

Table 5. Desaturase ratios of milk fatty acids in the mammary gland of cows fed diets supplemented with rubber seed oil and flaxseed oil, or in combination

\begin{tabular}{lcccccc}
\hline & \multicolumn{9}{c}{ Treatment $^{1}$} \\
$n_{\text {Desaturase ratios }}{ }^{2}$ & CON & RO & FO & RFO & \multirow{2}{*}{ SEM $^{3}$} & $P$-value \\
\cline { 2 - 5 } C14: 1 & $0.13^{\mathrm{b}}$ & $0.15^{\mathrm{a}}$ & $0.15^{\mathrm{a}}$ & $0.15^{\mathrm{a}}$ & 0.006 & $<0.01$ \\
C16:1 & $0.04^{\mathrm{c}}$ & $0.07^{\mathrm{a}}$ & $0.06^{\mathrm{b}}$ & $0.06^{\mathrm{ab}}$ & 0.003 & $<0.01$ \\
CLA 1 cis 9 & $0.66^{\mathrm{b}}$ & $0.69^{\mathrm{a}}$ & $0.70^{\mathrm{a}}$ & $0.70^{\mathrm{a}}$ & 0.008 & $<0.01$ \\
\hline
\end{tabular}

${ }^{\mathrm{a}-\mathrm{c}}$ Means in the same row with different superscripts differ significantly for treatment effect.

${ }^{1}$ Cows were fed a basal diet (control; CON) or basal diet supplemented with either $4.0 \%$ rubber seed oil (RO), $4.0 \%$ flaxseed oil (FO), or $2.0 \%$ rubber seed oil $+2.0 \%$ flaxseed oil (RFO). The CON diet was also used for feeding during the pretrial period.

${ }^{2}$ Desaturase indexes are ratio of the $\Delta^{9}$-desaturase product divided by the sum of the $\Delta^{9}$-desaturase productto-substrate, as described in the Materials and Methods. For example, the desaturase index for CLA would be (C18:2 cis-9,trans-11)/(C18:1 trans- $11+\mathrm{C} 18: 2$ cis-9,trans-11).

${ }^{3}$ Standard error of least squares means. 
Table 6. Blood parameters of cows fed diets supplemented with rubber seed oil and flaxseed oil, or in combination

\begin{tabular}{llllllr}
\hline \multirow{2}{*}{$\begin{array}{l}\text { Blood parameter, mmol/L (unless } \\
\text { otherwise noted) }\end{array}$} & \multicolumn{9}{c}{ Treatment $^{1}$} & & \\
\cline { 2 - 4 } & CON & RO & FO & RFO & SEM $^{2}$ & $P$-value \\
\hline Glucose & $3.48^{\mathrm{b}}$ & $3.92^{\mathrm{a}}$ & $3.95^{\mathrm{a}}$ & $3.82^{\mathrm{a}}$ & 0.102 & $<0.01$ \\
Triglycerides & 0.11 & 0.12 & 0.12 & 0.12 & 0.004 & 0.66 \\
Cholesterol & $5.76^{\mathrm{b}}$ & $7.54^{\mathrm{a}}$ & $8.26^{\mathrm{a}}$ & $7.45^{\mathrm{a}}$ & 0.702 & $<0.01$ \\
Phospholipids & 3.32 & 3.27 & 3.56 & 3.13 & 0.225 & 0.61 \\
High-density lipoprotein cholesterol & 1.73 & 1.88 & 1.91 & 1.73 & 0.094 & 0.41 \\
Low-density lipoprotein cholesterol & $0.35^{\mathrm{b}}$ & $0.52^{\mathrm{a}}$ & $0.56^{\mathrm{a}}$ & $0.50^{\mathrm{a}}$ & 0.052 & 0.03 \\
Insulin, $\mu \mathrm{IU} / \mathrm{mL}$ & 6.87 & 6.55 & 7.73 & 7.27 & 0.950 & 0.35 \\
Growth hormone, ng/mL & 0.82 & 0.91 & 0.92 & 0.99 & 0.135 & 0.85 \\
NEFA & $0.12^{\mathrm{c}}$ & $0.17^{\mathrm{b}}$ & $0.21^{\mathrm{a}}$ & $0.22^{\mathrm{a}}$ & 0.011 & $<0.01$ \\
BHB & 0.69 & $0 . .79$ & 0.73 & 0.80 & 0.231 & 0.16 \\
\hline
\end{tabular}

${ }^{a-c}$ Means in the same row with different superscripts differ significantly for treatment effect.

${ }^{1}$ Cows were fed a basal diet (control; CON) or basal diet supplemented with either $4.0 \%$ rubber seed oil (RO), $4.0 \%$ flaxseed oil (FO), or $2.0 \%$ rubber seed oil $+2.0 \%$ flaxseed oil (RFO). The CON diet was also used for feeding during the pretrial period.

${ }^{2}$ Standard error of least squares means.

mammary gland (Harvatine et al., 2009). Nonesterified fatty acids, cholesterol, phospholipids, triglycerides, LDLP, and HDLP are important components of blood lipid. Moreover, preformed fatty acids taken up by the mammary gland can arise either from plasma NEFA, chylomicron, or very low-density lipoproteins (Chilliard et al., 2000). Nonesterified fatty acid uptake is directly related to body fat mobilization (Chilliard et al., 1984), and in the present research the concentrations of glucose, cholesterol, LDLP, and NEFA in blood was higher

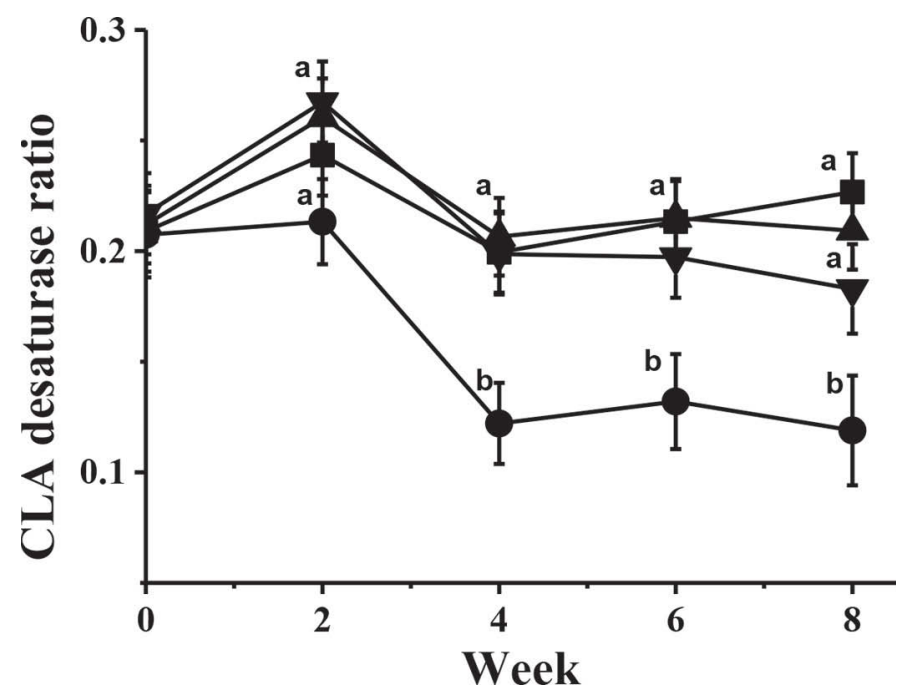

Figure 3. Average CLA desaturase ratio of treatment groups at wk $0,2,4,6$, and 8 . Control $(\mathrm{CON} ; \square)=$ diet without added oils rubber seed oil $(\mathrm{RO} ; \boldsymbol{\bullet})=\mathrm{CON}$ diet including rubber seed oil at $4 \%$ of DM; flaxseed oil $(\mathrm{FO} ; \mathbf{\Delta})=\mathrm{CON}$ diet including flaxseed oil at $4 \%$ of DM; rubber seed and flaxseed oil $(\mathrm{RFO} ; \mathbf{\nabla})=\mathrm{CON}$ diet including rubber seed oil at $2 \%$ of DM plus flaxseed oil at $2 \%$ of DM. Data were presented as the mean \pm SEM $(n=12)$. Means at the same week point with different letters $(\mathrm{a}, \mathrm{b})$ differ significantly for treatment effect.
$(P<0.05)$ in cows that were fed rubber seed oil or flaxseed oil than in the CON group (Table 6). Others have also observed that the concentrations of cholesterol, lipoprotein cholesterol, and NEFA in the blood plasma will increase in cows fed fats (Bu et al., 2007). These results may be attributed to triglyceride-rich lipoproteins being secreted into the lymphatic system and eventually released into the main blood circulation via the thoracic duct.

Blood phospholipids, growth hormone, insulin, and BHB remained relatively unchanged $(P>0.05)$ when rubber seed oil or flaxseed oil was supplemented (Table 6). Phospholipids are structural components of lipoproteins and provide fatty acids for cholesteryl ester formation in the plasma, but they are not a primary transport form of lipids (Spector, 1984). Consequently, oil supplements have not influenced the concentration of phospholipids in the blood. Supplementing oil or fat had no effect on insulin and growth hormone concentrations, which corroborates previously observed result (Bu et al., 2007). Evidence indicates that BHB concentrations remain stable after the addition of fats and the absence of an increase in ketone concentrations during periods of elevated NEFA suggests that the capacity to oxidize fatty acids to $\mathrm{CO}_{2}$ was not exceeded (Grummer and Carroll, 1991).

\section{CONCLUSIONS}

Supplementing cows' diets with rubber seed oil and flaxseed oil, separately or in combination, at $4 \%$ of the dietary DM increases milk production and results in milk with higher nutritive value by increasing the healthy fatty acids (ALA, VA, and CLA) in milk fat. Additionally, the increase of ALA, and CLA in milk 
from cows fed a mix of RO and FO (50:50) was greater than with cows that were fed RO separately.

\section{ACKNOWLEDGMENTS}

We gratefully acknowledge Liam A. Sinclair at Harper Adams University (Newport, UK), and Sander Van de Moortel and Peter Mortimer from ICRAF East and Central Asia (Kunming, China) for their assistance with editing this paper. This research was supported by research programs from the Ministry of Science and Technology of China (2012BAD12B02), the Agricultural Science and Technology Innovation Program (ASTIP-IAS07), the State Key Laboratory of Animal Nutrition (2004DA125184G1103) and the Key Product Development Program of the Yunnan Provincial Department of Sciences and Technology. Additional support came from the CGIAR Research Program 6: Forests, Trees \& Agroforestry.

\section{REFERENCES}

Allen, M. S. 2000. Effects of diet on short term regulation of feed intake by lactating dairy cattle. J. Dairy Sci. 83:1598-1624.

Allred, S. L., T. R. Dhiman, C. P. Brennand, R. C. Khanal, D. J. McMahon, and N. D. Luchini. 2006. Milk and cheese from cows fed calcium salts of palm and fish oil alone or in combination with soybean products. J. Dairy Sci. 89:234-248.

AOAC International. 2000. Official Methods of Analysis. 17th ed. AOAC International, Arlington, VA.

Bashar, M. A., and S. Jumat. 2010. Toxicity study of Malaysian rubber (hevea brasiliensis) seed oil as rats and shrimps tests. Asian. J. Biochem. 5:33-39.

Bauman, D. E., B. A. Corl, L. H. Baumgard, and J. M. Griinari. 2001. Conjugated linoleic acid (CLA) and the dairy cow. Pages 221-250 in Recent Advances in Animal Nutrition. P. C. Garnsworthy and J. Wiserman, ed. Nottingham University Press, Nottingham, UK.

Baumgard, L. H., E. Matitashvili, B. A. Corl, D. A. Dwyer, and D. E. Bauman. 2002. trans-10, cis-12 conjugated linoleic acid decreases lipogenic rates and expression of genes involved in milk lipid synthesis in dairy cows. J. Dairy Sci. 85:2155-2163.

Benchaar, C., G. A. Romero-Perez, P. Y. Chouinard, F. Hassanat, M. Eugene, H. V. Petit, and C. Cortes. 2012. Supplementation of increasing amounts of linseed oil to dairy cows fed total mixed rations: Effects on digestion, ruminal fermentation characteristics, protozoal populations, and milk fatty acid composition. J. Dairy Sci. 95:4578-4590.

Bu, D. P., J. Q. Wang, T. R. Dhiman, and S. J. Liu. 2007. Effectiveness of oils rich in linoleic and linolenic acids to enhance conjugated linoleic acid in milk from dairy cows. J. Dairy Sci. 90:998-1007.

Burdge, G. C. 2006. Metabolism of alpha-linolenic acid in humans. Prostaglandins Leukotr. Essent. Fatty Acids 75:161-168.

Chilliard, Y., A. Ferlay, R. M. Mansbridge, and M. Doreau. 2000. Ruminant milk fat plasticity: Nutritional control of saturated, polyunsaturated, trans and conjugated fatty acids. Ann. Zootech. 49:181-205.

Chilliard, Y., J. Robelin, and B. Remond. 1984. In vivo estimation of body lipid mobilization and reconstitution in dairy cattle. Can. J. Anim. Sci. 64(Suppl.):236-237.

Corl, B. A., L. H. Baumgard, D. A. Dwyer, J. M. Griinari, B. S. Phillips, and D. E. Bauman. 2001. The role of delta (9)-desaturase in the production of cis-9, trans-11 CLA. J. Nutr. Biochem. 12:622-630.
Dai, X. J., C. Wang, and Q. Zhu. 2011. Milk performance of dairy cows supplemented with rapeseed oil, peanut oil and sunflower seed oil. Czech J. Anim. Sci. 56:181-191.

DePeters, E. J., and J. P. Cant. 1992. Nutritional factors influencing the nitrogen composition of bovine milk: A review. J. Dairy Sci. 75:2043-2070.

Flowers, G., S. A. Ibrahim, and A. A. AbuGhazaleh. 2008. Milk fatty acid composition of grazing dairy cows when supplemented with linseed oil. J. Dairy Sci. 91:722-730.

Fossati, P., and L. Prencipe. 1982. Serum triglycerides determined colorimetrically with an enzymethat produces hydrogen peroxide. Clin. Chem. 28:2077-2080.

Givens, D. I. 2008. Session 4: Challenges facing the food industry in innovating for health. Impact on CVD risk of modifying milk fat to decrease intake of SFA and increase intake of cis-MUFA. Proc. Nutr. Soc. 67:419-427.

Givens, D. I. 2015. Manipulation of lipids in animal-derived foods: Can it contribute to public health nutrition? Eur. J. Lipid Sci. Technol. 117:1306-1316.

Glasser, F., M. Doreau, A. Ferlay, and Y. Chilliard. 2007. Technical note: Estimation of milk fatty acid yield from milk fat data. J. Dairy Sci. 90:2302-2304

Gómez-Cortés, P., A. Bach, P. Luna, M. Juárez, and M. A. de la Fuente. 2009. Effects of extruded linseed supplementation on n-3 fatty acids and conjugated linoleic acid in milk and cheese from ewes. J. Dairy Sci. 92:4122-4134.

Griinari, J. M., B. A. Corl, S. H. Lacy, P. Y. Chouinard, K. V. V. Nurmela, and D. E. Bauman. 2000. Conjugated linoleic acid is synthesized endogenously in lactating dairy cows by $\Delta^{9}$-desaturase. J. Nutr. 130:2285-2291

Grummer, R. R., and D. J. Carroll. 1991. Effects of dietary fat on metabolic disorders and reproductive performance of dairy cattle. J. Anim. Sci. 69:3838-3852.

Harvatine, K. J., Y. R. Boisclair, and D. E. Bauman. 2009. Recent advances in the regulation of milk fat synthesis. Animal 3:40-54.

Hussein, M., K. H. Harvatine, W. M. P. B. Weerasinghe, L. A. Sinclair, and D. E. Bauman. 2013. Conjugated linoleic acid-induced milk fat depression in lactating ewes is accompanied by reduced expression of mammary genes involved in lipid synthesis. J. Dairy Sci. 96:3825-3834.

Kaylegian, K. E., D. A. Dwyer, J. M. Lynch, D. E. Bauman, J. R. Fleming, and D. M. Barbano. 2009. Impact of fatty acid composition on the accuracy of mid-infrared fat analysis of farm milks. J. Dairy Sci. 92:2502-2513.

Kelsey, J. A., B. A. Corl, R. J. Collier, and D. E. Bauman. 2003. The effect of breed, parity, and stage of lactation on conjugated linoleic acid (CLA) in milk fat from dairy cows. J. Dairy Sci. $86: 2588-2597$.

Kramer, J. K. C., V. Fellner, M. E. R. Dugan, F. D. Sauer, M. M. Mossoba, and M. P. Yurawecz. 1997. Evaluating acid and base catalysts in the methylation of milk and rumen fatty acids with special emphasis on conjugated dienes and total trans fatty acids. Lipids 32:1219-1228.

Lichtenstein, A. H., L. M. Ausman, W. Carrasco, J. L. Jenner, L. J. Gualtieri, B. R. Goldin, J. M. Ordovas, and E. J. Schaefer. 1993. Effects of canola, corn, and olive oils on fasting and postprandial plasma lipoproteins in humans as part of a National Cholesterol Education Program Step 2 diet. Arterioscler. Thromb. 13:15331542.

Lock, A. L., and P. C. Garnsworthy. 2002. Independent effects of dietary linoleic and linolenic fatty acids on the conjugated linoleic acid content of cows' milk. Anim. Sci. 74:163-176.

Loor, J. J., A. Ferlay, A. Ollier, K. Ueda, M. Doreau, and Y. Chilliard. 2005. High-concentrate diets and polyunsaturated oils alter trans and conjugated isomers in bovine rumen, blood, and milk. J. Dairy Sci. 88:3986-3999.

Martin, C., J. Rouel, J. P. Jouany, M. Doreau, and Y. Chilliard. 2008. Methane output and diet digestibility in response to feeding dairy cows crude linseed, extruded linseed, or linseed oil. J. Anim. Sci. $86: 2642-2650$. 
Martínez Marín, A. L., P. Gómez-Cortés, A. G. Gómez Castro, M. Júarez, L. M. Pérez Alba, M. Pérez Hernández, and M. A. de la Fuente. 2011. Animal performance and milk fatty acid profile of dairy goats fed diets with different unsaturated plant oils. J. Dairy Sci. 94:5359-5368.

Matsubara, C., Y. Nishikawa, Y. Yoshida, and K. Takamura. 1983. A spectrophotometric method for the determination of free fatty acid in serum using acyl-coenzyme a synthetase and acyl-coen-zyme an oxidase. Anal. Biochem. 130:128-133.

McMurray, C. H., W. J. Blanchflower, and D. A. Rice. 1984. Automated kinetic method for D-3-hydroxybutyrate in plasma or serum. Clin. Chem. 30:421-425.

McNamara, J. R., and E. J. Schaefer. 1987. Automated enzymatic standardized lipid analyses for plasma and lipoprotein fractions. Clin. Chim. Acta 166:1-8.

Moallem, U., D. Vyas, B. B. Teter, P. Delmonte, M. Zachut, and R. A. Erdman. 2012. Transfer rate of alpha-linolenic acid from abomasally infused flaxseed oil into milk fat and the effects on milk fatty acid composition in dairy cows. J. Dairy Sci. 95:5276-5284.

NRC. 2001. Nutrient Requirements of Dairy Cattle. 7th rev. ed. Natl Acad. Press, Washington, DC.

People's Republic of China. 2004. Feeding Standard of Dairy Cattle. China NY/t34 (China NongYe HangYe Biaozhun/Tuijian-34). China Agricultural Publisher, Beijing, China.

Petit, H. V. 2003. Digestion, milk production, milk composition, and blood composition of dairy cows fed formaldehyde treated flaxseed or sunflower seed. J. Dairy Sci. 86:2637-2646.

Reynaert, R., and P. Franchimont. 1974. Radioimmunoassay of bovine growth hormone. Ann. Endocrinol. (Paris) 35:139-148.

Sampelayo, M. R. S., Y. Chilliard, P. Schmidely, and J. Boza. 2007. Influence of type of diet on the fat constituents of goat and sheep milk. Small Rumin. Res. 68:42-63.

Shingfield, K. J., Y. Chilliard, V. Toivonen, P. Kairenius, and D. I. Givens. 2008. Trans-fatty acids and bioactive lipids in ruminant milk. Adv. Exp. Med. Biol. 606:3-65.

Shingfield, K. J., C. K. Reynolds, G. Hervas, J. M. Griinari, A. S. Grandison, and D. E. Beever. 2006. Examination of the persistency of milk fatty acid composition responses to fish oil and sunflower oil in the diet of dairy cows. J. Dairy Sci. 89:714-732.

Sinclair, L. A., W. M. P. B. Weerasinghe, R. C. Wilkinson, M. J. de Veth, and D. E. Bauman. 2010. A supplement containing trans- 10,cis-12 conjugated linoleic acid reduces milk fat yield but does not alter organ weight or body fat deposition in lactating ewes. J. Nutr. 140:1949-1955.

Spector, A. A. 1984. Plasma lipid transport. Clin. Physiol. Biochem. $2: 123-134$

Starr, J. I., D. L. Horwitz, and A. H. Rubenstein. 1979. Insulin, proinsulin, and C-peptide. Pages 289-311 in Methods of Hormone Radioimmunoassay. B. M. Jaffe, and H. L. Behrman, ed. Academic Press, New York, NY.

Sukhija, P. S., and D. L. Palmquist. 1988. Rapid method for determination of total fatty acid content and composition of feedstuffs and feces. J. Agric. Food Chem. 36:1202-1206.

Trinder, P. 1969. Determination of glucose in blood using glucose oxidase with an alternative oxygen acceptor. Ann. Clin. Biochem. 6:24-27.

Tsiplakou, E., and G. Zervas. 2013. The effect of fish and soybean oil inclusion in goat diet on their milk and plasma fatty acid profile. Livest. Sci. 155:236-243.

Turpeinen, A. M., M. Mutanen, A. Aro, I. Salminen, S. Basu, D. L. Palmquist, and J. M. Griinari. 2002. Bioconversion of vaccenic acid to conjugated linoleic acid in humans. Am. J. Clin. Nutr. $76: 504-510$.

Tyrrell, H. F., and J. T. Reid. 1965. Prediction of the energy value of cow's milk. J. Dairy Sci. 48:1215-1223.

Van Soest, P. J., J. B. Robertson, and B. A. Lewis. 1991. Methods for dietary fiber, neutral detergent fiber, and nonstarch polysaccharides in relation to animal nutrition. J. Dairy Sci. 74:3583-3597.

Whitlock, L. A., D. J. Schingoethe, A. R. Hippen, K. F. Kalscheur, R. J. Baer, N. Ramaswamy, and K. M. Kasperson. 2002. Fish oil and extruded soybeans fed in combination increase conjugated linoleic acids in milk of dairy cows more than when fed separately. J. Dairy Sci. 85:234-243.

Yang, G., D. P. Bu, J. Q. Wang, Khas-Erdene, L. Y. Zhou, and J. J. Loor. 2012. Duodenal infusion of alpha-linolenic acid affects fatty acid metabolism in the mammary gland of lactating dairy cows. J. Dairy Sci. 95:5821-5830.

Zheng, H. C., J. X. Liu, J. H. Yao, Q. Yuan, H. W. Ye, J. A. Ye, and Y. M. Wu. 2005. Effects of dietary sources of vegetable oils on performance of high-yielding lactating cows and conjugated linoleic acids in milk. J. Dairy Sci. 88:2037-2042. 